\title{
Implications of Compulsory Car Accident Insurance Comparative Study
}

\author{
Nadia Yasa and Reema AlQaruty b \\ a \\ College of law, Al Falah University, UAE

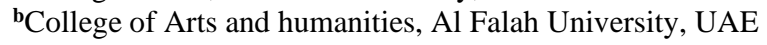

Article History: Received: 11 January 2021; Accepted: 27 February 2021; Published online: 5 April 2021

\begin{abstract}
Compulsory civil liability insurance on car accidents is one of the most important topics, which aims to achieve traffic safety and reduce car accidents. Today, car accidents constitute a great danger to human life as they cause different types of physical and moral damages. This study, however, attempts to highlight the effectiveness of compulsory insurance in providing legal protection for damages resulting from car accidents. Such protection can be achieved through the process of creating legal mechanism to enable injured people to refer to insurance companies. It is quite apparent that nobody can deny the importance of insurance and its influence on people's lives. Insurance companies nowadays have become an essential cornerstone in the economy of any country. An insurance contract has legal consequences on the parties, which leads to corresponding obligations. These parties are committed to comply with these obligations otherwise, any violation will be treated as per the prescribed legal sanctions. In conclusion, any research or study on the compulsory insurance system whether in the Emirati law or in Islamic Sharia is highly recommended as part of the attempts to solve and rectify any legal and legitimate problems in this system. An essential objective of the Islamic Sharia is to achieve all fair interests of people. Arab and international legislation consider car insurance compulsory with some exceptions in order to compensate all those affected by a car accident. Arab and other foreign laws as well as the legitimate ones have differed in their choices of car insurance basis. Many legislations in the field of compulsory insurance have limited the right of compensation to body damage. Some other legislations have covered damages of property. Most legislations have not specified the amount of compensation that the insurer is obliged to pay in case of injury, death, or property damages. companies.
\end{abstract}

Keywords: Car Accident Insurance, Legal protection, Insurance Contract.JEL Classification: K00, K20, K30.

\section{Introduction}

Due to the development that all aspects of our modern life have witnessed, insurance has become an important issue, and legislators have to intervene to make it compulsory where necessary such as the compulsory car accident insurance (Peden et al., 2004). The decision to make car accident insurance compulsory was highly required as a procedure to ensure on one hand that victims receive compensation, and on the other hand, to protect the financial liability of those who cause the damage (Peden et al., 2004). The compulsory insurance contract is governed by a bilateral relationship between the client and the company. This relationship raises many problems in the application, and the attempt of each party to evade responsibility as the concept of insurance is based on the idea of distributing damages resulting from an accident on a group of individuals (Baker, 1993). Insurance is seen as one of the most important means achieved by humanity to face social risks and mitigate their effects. Man, through his daily life is subject to different types of dangers, which threaten him in person such as death and disease, as well as other types that endanger his money and property (Yas, Alsaud, Almaghrabi, Almaghrabi, \& Othman, 2021). Danger indeed threatens people everywhere and all the time, while driving their cars or during work or even while staying at home (Council, 2006). Moreover, the jurisprudence of lawmakers has its great influence on building solid ground for establishing disciplined insurance companies as well as protecting and compensating clients (Griffith, 2005). In our current study, we attempt to explore the implications of compulsory car accident insurance and their relevance to judicial legislation, meanwhile, monitoring developments in the terms and conditions of compulsory insurance contracts.

Importance of research is attributed to the following reasons. Firstly, Insurance of different types of activities has widely spread raising new social and legal responsibilities especially those related to the triple relationship between the injured, those who cause the damage and the insurance company. Such relationship has brought many problems in the application with the attempt of each party to evade responsibility. Secondly, Laws have been legislated to regulate the provisions of insurance. Some types of insurance have been made compulsory such as compulsory car accident insurance. Thirdly, the rights and obligations resulting from an insurance contract and affect its legal and legitimate nature. The research also considers identification of such impact within the existence of a third affected party (Mullerat, 2010).

There are aims of research can be summarized as follows, Analyzing the legal and legitimate rights and obligations resulting from signing insurance contracts. Identifying the nature of the risk insured on which the company's obligation is specified with the limits and restrictions and their effect on the injured. Finding solutions to the problems that might result from signing insurance contracts within the framework of relevant laws and legislation. Acquainting people with legal knowledge so that everybody becomes aware of their rights and obligations as per the insurance contract the sign. Originating the insurance idea from a legal and legitimate point of view. However, There are research questions focuses on the following issues such as What are the main features 
of a compulsory insurance contract? What kind of rights and obligations are imposed on the parties of this contract? What problems are caused by signing such a contract? To what extent could legislators treat the various aspects of compulsory car accident insurance? To what extent are insurance companies committed to pay compensation?

\section{Literature Review}

For the purpose of covering all aspects, theoretical and practical, our research has been divided into two main parts preceded by general framework of compulsory insurance, its liability as well as legal and legitimate nature, and Implications of compulsory insurance and its civil liability

\subsection{General framework of compulsory insurance, its liability as well as its legal and legitimate nature}

People resort to insurance as a procedure through which they protect themselves against different types of dangers, which threaten their safety (Beck, 1992). An insurance contract is signed between an insurance company and a client who is committed to pay an amount of money to this company. In return, if some kind of risk or danger occurs to this client, the insurance company shall pay the insured specific compensation (Cowley \& Cummins, 2005). The word "insurance" is thought to derive from "ensuren" or "insuren", meaning, "to give a formal assurance". This was a much broader meaning than what is associated with "insure" though we do still use the word "ensure". The word "ensure" is itself a compound word which incorporates the prefix "en"(meaning, "make") and old French "seur"). Nowadays, the term "insurance" is utilized to refer to private contracts issued by Insurance companies. According to these contracts, these insurance companies are obliged to pay amounts of money to second parties whenever a specific accident occurs to those parties. It should be also noted that the second party of an insurance contract should pay certain installments to the first party (Vickrey, 1968).

The term of "insurance", therefore, can be defined as an agreement between two parties according to which the first party shall pay certain compensation to the second party if some kind of danger occurs to the latter within a limited period. On the other hand, the second party shall pay an amount or amounts of money, which in total is less than the amount to be paid by the first party. The first party, the insurer, in such contract can be an individual or a group. It may represent a cooperative society, a shareholding company, the government, or other types of insurance companies while the second party is the insured. Insurance in general is optional, but in some cases, it is made compulsory for specific reasons. Protection is one of them. Modern legislation, however, is keen to make insurance compulsory in certain areas to ensure that certain groups of people can receive their compensation in case of having an accident (Abulleil, 1995).

Insurance is strongly associated with an economic theory as it deals with losses of fortune that belong to individuals, groups, companies and projects. Social and economic developments have led to appearance of new types of insurance. Accident insurance is one of them. Establishment of this type of insurance is attributed to three main factors: a. industrial revolution; b. business development; and c. evolution of transportation (see Sabir, 1993). However, the idea of insurance is mainly based on cooperation in repairing damages and mitigating the consequences and disadvantages that a person cannot bear alone. Many of the provisions of Islamic Sharia are based on this idea, such as Zakat, spending on relatives and charging the sane person with blood money and many other examples, which focus on collaboration in righteousness, charity, piety and solidarity for the purpose of fragmenting risks and warding off the effects of calamities. These actions are all permissible among contemporary jurists (Al-Qaradaghi, 1979). The idea of insurance, therefore, is completely consistent with the purposes of Islamic Sharia and its provisions. Besides, insurance, like any other transaction, does not need any kind of reasoning to determine its permissibility. Simply, because the majority of scholars approve the principle permissibility in transactions. Instead, searching for evidence that might indicate prohibition is required. After that, the validity of inference shall be considered through the process of discussion (Al-Zayla'i, Othman Bin Ahmed, 1314). As for the jurisprudential dispute on this issue, it is not a subject for study in our current research.

A daily observation of traffic on roads can lead us to conclude that all kinds of vehicles have largely increased. Cars, indeed, have become unavoidable and very necessary for our daily life. Such increase in vehicles has caused a huge soar in accidents with all kinds of damages whether in people's lives or in their properties. Consequently, a compulsory insurance law has been issued in many countries in the world in an attempt to control the situation. Compulsory insurance can be defined as a contract imposed by law on the car's owner who cannot use it or permits others to use it without insurance (Haikal, 1985). This procedure enables insurance companies to cover damages caused by car accidents to third parties. It is a contract according to which both the insurer and the insured are committed to compensate a third party (the one who is injured a car accident). For such type of insurance, companies issue compulsory insurance document against civil liability according to which a third party is compensated in his person or his property, and such process, indeed, is an essential part of the legitimate policy in Islamic Law.

Dangers are distributed among car owners by law, and therefore, they are forced to pay amounts of money when required if they cause accidents, and insurance companies will compensate victims of these accidents (James, 1948). Lawmakers have made car accident insurance compulsory to achieve two goals. Firstly, Providing safety and protection to car owners. Safety, however, has a jurisprudential basis in Islamic Law. It is indeed a matter of ensuring the road risks, and it has been exemplified when a man said to another, "Take this road. It is safe." The other man took the road, and he was robbed. If the first man has explicitly said, "I guarantee your safety", the situation will be totally different, and that is what an insurance contract represents. Secondly, compensating second and third parties for any losses, damages, or injuries caused by car accidents. 
Main features of compulsory car accident contracts can be summarized as follows, Compulsory insurance covers serious damages and injuries that occur to car owners (second party) as well as to others (third party) because of using cars. Compulsory insurance is considered as a contract in-kind and not a contract of personal consideration. In other words, it covers all car risks and not like the other one, which covers only the mistakes committed by the insured. Article 8 of the Compulsory Insurance Law stipulates that the injured person shall acquire direct right without being affected by the status of the insured. Article 10 of the Compulsory Insurance Law stipulates that the insurer stands for the injured rather than for the insured. This article indeed confirms the in-kind consideration of the contract as well as the direct right given to the injured (Lemaire, 2013).

In a compulsory insurance contract, indemnity is a two-fold obligation. First obligation arises from a tort. Second obligation arises from the compulsory insurance contract which covers the tort so that the injured can gain the required compensation (Bovbjerg, Sloan, \& Blumstein, 1988). As for the first obligation, it can be viewed through the insured commitment to compensate the injured on the basis of tort. Nevertheless, this obligation and despite compulsoriness of insurance is incapable of reaching full compensation to the injured in car accidents. However, the second liability is based on the imposition of a legal obligation on the insurance company to compensate the affected people. The legal basis of the insured responsibility stands on two theories: the personal error theory and the objective theory of damage (Keeton, 1954). Whereas the insurer's liability is included in the terms and conditions of a compulsory insurance contract according to which the company is forced to compensate the affected. While the personal error theory considers the person as responsible only when he commits the mistake, the objective theory focuses on the damage itself, as the person who causes it is not mistaken (Robinson, 1975). Legislators use these theories as means or tools for compensation and achievement of justice among disputing parties.

The personal error theory has its roots in the Greek Philosophy, and its features are apparent in the Roman law. However, this theory has not been taken as a basis for responsibility in the old French law as shown in Doma's writings on civil laws. Later, it has been included in the French civil law, and article No. 1382 stipulates that," any action committed by man and causes damage to other people, the one who commits this action should compensate the injured ones" (see Murqus, 1971). The concept of error has become a basis for civil liability, not only in the French law but also in others, such as the Egyptian civil law, article No. 163, and the Iraqi civil law, articles 186 \& 204. As for the English civil law, the Law of Tort has appeared first in the form of judicial orders issued by the Supreme Court under its administrative authority. Those who are affected by any harmful act have to look for the judicial order that suits their case (see Law of Tort, 1946). The concept of error has been flexible, interpreted according to circumstances, morals and social habits of peoples.

Since the second half of the nineteenth century, social philosophical thoughts have widely spread theorizing an objective view about damage with an attempt to replace the personal error theory, which has lost its relevancy due to fast progress in the various fields of industry and use of deadly mechanical machines. Legislators then started to reject liability focusing on damage and causal relationship (Baert \& Da Silva, 2010). These attempts gradually led to establishing the objective theory of damage. This theory, however, took long time to be adopted everywhere in the world. For example, while it appeared in England as series of judicial orders added when they arise to the list of harmful acts already existing the general legislation, in France it took the form of alluring templates consistent with human conscience and principles of justice, but never included in the French law except certain cases (De Búrca \& Scott, 2006). The liability of the insurer is determined as per a contract with the insured, and the general rules confirm that only contractors are covered by the terms and conditions. Nevertheless, and in some cases, these rules are ignored to achieve interest to other people according to the requirement rule for the benefit of other people. Though such rule creates an obligation for the company to explicitly compensate the injured, it is an obligation overloaded with defenses and exceptions. Moreover, the company does not pay any compensation unless the contract elements of satisfaction, place and reason are solid and valid, and any problem in these elements will invalidate the contract and destroy the obligation (Shell, 1991).

The compulsory insurance law also creates a similar obligation, but of a different kind, unaffected by defenses and exceptions except what is related to cause and defects of will. The source of such obligation is either the law or the contract. At the beginning, jurisprudence and judiciary included the requirement rule for the benefit of other people in the insurance contract with an attempt to create direct relationship between the insurance company and those who are injured in car accidents, and thus finding suitable interpretation for direct compensation (Sultan, 1962). Though such opinion is reasonable and suitable due to the benefits achieved for the affected, there are many obstacles that hinder its achievement. In addition, contactors never had the intention to determine such direct right, and the nature of the contract itself does not allow any violation to the principle of relative effect. We should note that optional civil liability insurance does not include any requirement for the benefit of the affected in car accidents, and therefore, no direct obligation is forced on the insurance company. As for the compulsory insurance, the company is obliged to compensate the affected directly if the latter obtains a judgment, which determines the liability of the insured for the accident. This obligation is not based on a legal provision but included in the compulsory insurance contract.In conclusion, car accident insurance is of two types. The first type has a contractual basis in which the insured or the car owner is obliged to pay the insurance with no liability on the insurer. The second type is based on law rather than on the contract, and the relationship between the insured and the affected is legal. Accordingly, the affected in a car accident obtains compensation by law with no need to sign an insurance contract on the vehicle (Al-Azzawi, 2019). The nature of such insurance shall be compulsory and its rules are part of public discipline, which nobody can degrade or violate (Abulleil, 1995). 
Compulsory car accident insurance, in case of an accident, requires an evidence to be submitted by the insured so that the insurance company could compensate him for the damages. The insured, however, receives an amount commensurate with the value of the damage, unlike other types of insurance in which the beneficiary can claim for the full amount of compensation. Furthermore, the amount of compensation cannot be determined in a compulsory insurance until the risk has occurred, whereas in the types, it is possible to identify this amount on advance and when signing the contract. Besides, compulsory insurance is designed to release the insured from liability if other parties are affected by the accident he causes. The insurance company is committed to pay all amounts of compensation decided by the court to third parties (Fahmi, 2005). We should note that the insurance company also compensates all physical injuries caused by car accidents to third parties. Accordingly, there is no direct connection between the insured and third parties. Such independent treatment to the affected confirms the special nature of the compulsory insurance.

The compulsory insurance has also identified the risks that cause damages due to using a car compulsorily insured issued by an insurance company or any other institution authorized to issue documents (Shahada \& Abdallah, 1988:). A legal regulation has been established to avoid damage to the injured by setting restrictions on the use of the car by the insured so that if he violates this regulation, the injured person has the right to obtain his financial dues and compensation. These restrictions are not arbitrary, but cover the damages (Fahmi, 2005).

\subsection{Implications of compulsory insurance and its civil liability}

An insurance contract has legal effects on its parties creating corresponding obligations that should be fulfilled and implemented; otherwise, the party who violates these obligations shall be penalized by law. The effect of the contract may extend to third parties, i.e. possible beneficiaries. In this part of our research, we shall address the obligations that the contract imposes on the parties. A compulsory insurance contract is binding for both parties. In other words, it imposes specific obligations on them. The insurer, for instance, is obliged to cover the liability of the insured in case of a car accident. The legislator has carefully identified and included these obligations in the contract. Indeed, the establishment of an insurance contract of civil liability has some effects that are not defined by the general rules of liability insurance in the Civil Code. The insured is the second party in an insurance contract. This party has three features: a. he is the contractor who signs the contract with the insurer; $b$. he is threatened by danger against which he is insured; and c. he is the one who receives the insurance amount. These features might gather in one person, or they are distributed between two or among three persons (Jamal, 1998). The insured is committed to a set of obligations when signing the contract, during its validity, when a claim occurs, and during the lawsuit raised against him (Al-Deeb, 1993). Arabic legislations, such as the Emirati, the Egyptian, the Iraqi, and the Jordanian, stipulate these obligations. They are as follows.

This obligation is unlike other types of insurance, as it requires complete information about the insured person as well as the circumstances of the insured risk (Desouqi, 1955). This obligation is quite apparent in the compulsory car accident insurance in which the legislator has intervened to determine compulsoriness, amount of installment, and to impose the conditions of this type of insurance. The insured is responsible for the correctness and validity of the data required by law. The Emirati legislator, for example, has intervened to impose compulsoriness of insurance in the Federal Traffic Law No. 21, 1995, and the Executive Regulation by Resolution No. 120, 1997, as well as the unified insurance policy by Resolution No. 54, 1987. In addition, the insured is committed to inform the insurer with any new circumstances that may affect the insured risk and increase the possibility of its occurrence (IBID, 360). Article No. 16 of the Egyptian Civil Transactions Act, 1955 stipulates the insured shall notify the insurer within 72 hours of his/her knowledge, or knowledge of who represents them of any loss or car accident causing death or injury, or a claim for compensation. He should also provide the insurer with all letters, claims, warnings and declarations as soon as they are received (Al-Deeb, 1993).

Progress in technology and appearance of digital system has changed the procedures used in submitting the required data, becoming more required though much easier. However, the high interest of submitting information nowadays does not negate its existence in traditional contracts. The general theory of the contract has treated the issue within the range of will defects. Article No. 125/2, of the Egyptian Civil Transactions Code, No. 131, 1948 stipulates that, "deliberate silence for an incident or circumstances shall be considered fraudulent; otherwise, the insurer would not have concluded the contract, if he knew of the incident or such circumstances". Similarly, the Emirati Civil Transactions Code, No. 5, 1985, Article No. 186 refers to deliberate silence for an incident or circumstances that may affect concluding a contract. Legal regulation of contracts includes several references to obligation of providing information. In a procuration, for example, the authorized is obliged to provide the authorizer with all required information (see Khatir, 2001). In a bail, the debtor should inform the guarantor that the debt has been repaid. The data that the insured is committed to submit are of two types. Personal data: they are related to the identity of the insured that might affect the determination of the premium, such as his morals and keenness to fulfill obligations. Objective data: they focus on the intrinsic qualities and objective conditions surrounding the risk, such as age, health status (in life insurance), the nature of the insured thing, the material made of it, its purpose, and all related attributes if the insurance is on things.

The intervention of the legislator to unify insurance conditions and premium in this type of insurance is justified, as it covers a licensed car and a licensed driver and all this is governed by articles stipulated in the Traffic Law. Any violation to these conditions, such as using fake or invalid license, shall lead to penalizing the insured, and the insurance document is considered void. According to the general rules, the insured should pay premium on time. The insurer may require the premium to be paid in advance for each period of insurance, or the whole amount shall be paid when signing the contract. The insurer claims that payment in advance enables the 
company to compensate for any accident that may occur at any time by other clients. However, if the insured fails to pay premium, the insurer may excuse him and delay payment for a specific period as included in the insurance document (Mohammad Al-Siddiq, 2000). The period is 30 days after which the insurance validity is cancelled. During this period, the insured does not have insurance cover until the insurer takes a position, either to terminate the contract or to determine the date of payment of the next installment (Yas, Jusoh, Abbas, Mardani, \& Nor, 2020). However, in a compulsory civil liability insurance, the insurer does not need to impose such a condition, i.e. payment of premium on time. This is because the contract term is the period for which the vehicle license tax is paid. In other words, the insured is obliged to submit a new insurance document at the end of car licensing period. By this way, the insurer will receive the whole amount of insurance at the start of contracting (see Ogrese, 1992).

Payment of premium, therefore, is one of the main obligations, and the insured is the original debtor as long as he is the signatory on the contract whether he is the beneficiary or someone else. Payment of premium obligation shall be transferred to successors or trustees until the estate is divided and a new owner is determined (Hamid, 2003: 56). Finally, the insurer is keen collecting premiums at the headquarter of the company to avoid delay. According to a compulsory car accident insurance document, the insured shall notify the insurer within 72 hours of his/her knowledge, or knowledge of who represents them of any loss or car accident causing death or injury, or a claim for compensation. He should also provide the insurer with all letters, claims, warnings and declarations as soon as they are received (Al-Deeb, 1993). Consequently, the insured is obliged to inform the insurer at the occurrence of the insured risk, otherwise the insured shall be penalized. If the insured violates this obligation within a period identified in the contract, such as three or five days, the insured may lose his right to receive the insurance amount as long as there is an explicit, prominent and apparent condition in the policy to do so. This procedure is confirmed if the insured has failed to submit an acceptable excuse, or force majeure has prevented him from notifying the insurer on time (Desouqi, 1955). This notification shall be sent to the insurer or to another specific party, such as an office of expertise, a police station, or a fire department (IBID. 368).

The United Arab Emirates legislator in clause No. 5 of the general conditions of the unified insurance policy of the UAE considers the insured responsible for informing immediately the insurer when an accident occurs, or when danger is realized, and he can claim it without referring to the competent authority to investigate the accident. Article No. 5 of the UAE Federal Traffic Law, No. 21, 1995 confirms that a vehicle driver shall give his personal and vehicle data to any policeman present at the occurrence of an accident. If such accident results in damage to him or to other people, or to property owned by him or by others he shall provide all possible assistance to bring ambulance to the injured. He should also inform the nearest police station within a period not exceeding six hours unless the delay in reporting is attributed to an acceptable excuse (Khudhair, Jusoh, Mardani, Nor, \& Streimikiene, 2019). Finally, it is considerable to note that the insurer has no right to complain of any delay in informing about an accident and use it as an excuse to drop compensation. The insurer or the insurance company is the first party in a contract in which the second party is the insured. The insurer is committed to compensate the insured at the rise of civil liability due to a car accident, and claim of the injured for compensation. While the insured has to pay premium, the insurer should pay compensation as per an agreement or adjudication in case of death or body injury (Fahmi, 2005). We will attempt to describe the main obligations of the insurer in the following sub-sections.

In a compulsory car accident insurance, both the Emirati and the Egyptian legislators confirm that the insurer is obliged to pay an amount of compensation as per adjudication to those who deserve it. The third item of the UAE unified insurance policy refers to the covered risks stating that the company shall be committed to the case judgement and pay the amount of compensation regardless of its value. On the other hand, the provisions of the UAE and Egyptian cassation confirm that the insurer is obliged to pay what is determined by the court in favor of the injured (Mohammad Al-Siddiq, 2000). As for the limit of the amount of compensation according to the general rules, it is possible to agree on a maximum amount for the whole period of insurance, or for just one accident. The two parties may also agree that part of compensation due to the injured shall be paid by the insured. The legislator has taken into consideration that the insurer's obligation is subject for limitation in many ways. It is a limited obligation where the source of liability is a car accident, covering only the death and the body injuries that affect people. It does not include damages caused to properties. According to article No. 5 of the Law No. 652,1955 , the insurer shall cover the civil liability arising from death or body injuries, which affect any person in a car accident.

Since the criminal punishment is personal, the insurer is not obliged to cover such liability, or insure its effects. The insurer's obligation is limited to the civil liability of the insured, which expands to cover the contractual liability as well as the tort of the insured. While an accident entails a contractual liability for the insured, such as taxis and buses, the insured's liability is tort represented in the injury of other people (Abraham $\&$ Rabin, 2019). This liability rises at the occurrence of a collision between two vehicles causing body injuries to the passengers of these two cars or just one of them. The insurer is committed to cover the civil liability resulting from this accident. In other words, the insurer should compensate the drivers as well as the passengers. They all benefit from the compulsory car accident insurance even if they are excluded. The insurance company, therefore, should pay the amount of compensation for all the affected as per an adjudication (Vickrey, 1968).

According to an insurance contract, the insurer, being the first party, is obliged to cover the civil liability of the insured. The insurer, as a guarantor, shall compensate the insured and the injured people at the occurrence of an accident provided that the insurance contract between the two parties is still valid. However, if the accident 
occurs after the expiry of the insurance period, the insurer shall not bear any compensation (Greenblatt, 1997). Instead, the person responsible for the accident shall be liable as long as there is no subsequent insurance to cover liability. The majority of legislators, nowadays, support the right of the others affected by a car accident to refer directly to insurer for collecting their compensation. Indeed, it is no longer considered as a violation to the relativity of the contract's effects. The difficulty, however, lies in finding legal support for this case. Our attempt in the following sub-sections is to deal with the different views of jurisprudence, and the position of legislation as well as the comparative judiciary (Aguilar, Ward, \& Smith Sr, 2003).

The first thing that may come to the mind of the injured because of a car accident is to prosecute the offender. This situation often ends with either reconciliation or by referral to the courts (Petersilia, 2001). The offender can deny liability and defend himself by statute of limitations or discharge. Reconciliation, however, as we stated before, remains a major solution. In some cases, the perpetrator may accept responsibility and compensate the injured with an amount of money. In other cases, the offender could be a bankrupt person. The injured, hence, shall resort to traditional methods to ensure his right, such as a policy suit, indirect lawsuit, or attachment of the debtor's property with third parties. Most of the time, indirect lawsuit leads to nothing and the injured loses his right due to huge number of creditors (Al-Ateer, 1995). Apart from all these rules and methods, compulsory insurance has offered the injured a direct action for collecting compensation. By this way, the injured can refer to the insurance company to obtain compensation for the damage caused by the insured within the value of the insurance (Al-Sanhouri, 2004).

An example for direct suit, the Court of Cassation in Dubai issued recently a court ruling concerning the right of the injured Ali Awad in the field of car insurance. In this ruling the court said, "in accordance with the judgment of this court, a third party injured in a car accident, derives his right to compensation for injury, death or damage from the insurance contract though he is not a party. Accordingly, the injured shall receive this right, as the case with all the defenses related thereto, at the time of the incident and within the limits specified by the insurance contract (Cotran \& Lau, 2005). Hence, the insurer may hold before third parties the conditions included therein, which could have been invoked in the face of the insured or of his judgment, such as the authorized licensed driver to drive the insured vehicle" (see appeal No. 384, 1997, Dubai Cassation Court, published in Al-Bayan, 27 March 1998, p. 29).

The preliminary draft of the Egyptian Law, article No. 1122, includes the following text: "It shall not be permissible to pay to the injured the amount of insurance agreed upon in whole or in part as long as the injured is not compensated for the damages caused by the insured." The review committee as well as the House of Representatives approved the text, but the Senate deleted it because it is believed that such minor details shall be regulated by special laws (Al-Sanhouri, 1964). Consequently, the Egyptian Civil Law does not contain a text that determines a direct lawsuit for the injured against the insurer. This is assured by the Court of Cassation when saying, "A direct claim shall not be granted to the aggrieved unless the insurance policy includes a condition in favor of others. In this case, it is necessary to refer to the general rules to know whether the insurance contract includes a condition for the benefit of others, or it is just an agreement between the contracting parties. The Iraqi Law gives the right to the injured alone to obtain the insurance amount, making it as part of the total provisions and not of the insurance details. Article No. 1006 confirms that only the injured shall receive the insurance amount agreed upon, in whole or in part, as long as he has not been compensated (see Mursi, 1952).

The English Law does not give any right to the injured for compensation in case of the insured's insolvency or liquidation of the company on the amount of the insurance that the insured has with the insurer (Halpern, Trebilcock, \& Turnbull, 1980). Indeed the security amount is included in the general security of the insured. The only option left for the injured is to prove his right as a normal creditor. Before the issuance of this law, there were two car accident cases, in which civil liability was in favor of others. These two cases are: Tinline vs. White Cross Insurance Association, James vs. British General Insurance Co. Both cases are related to civil liability insurance in favor of others resulted from a mistake committed by the insured who causes injury or death to other people while driving a car. Although car insurance was not compulsory at that time, both drivers were negligent in causing damage to others, resulting in the death of some pedestrians (Schroll, 2014). However, they were not deliberate. In the first case, the driver was over speeding when he committed the accident, and in the second case, the driver was drunken. Nevertheless, there was no evidence for intentional action to cause damage to others. The court ruled in both cases that the insurer should compensate the insured for his civil liability to others because the act was not intentional. In a third case, (Hardy vs. Motor Insurers Bureau) the action was proved to be intentional, and therefore, compensation was against law (Birds, Sweet \& Maxwell, 1988).

This case is a deliberate damage caused by uninsured car thief. The injured sued the insurer who paid the compensation on the basis of public discipline. In its ruling, the Court of Appeal made it clear that if the thief himself had tried to obtain insurance protection, his application would have been rejected (Trebilcock, 1988). Luckily, the 1972 Traffic Law has offered the injured to demand compensation directly from the thief's insurer. If the thief is not insured, the injured has the right to demand compensation from Car Insurance Office. According to a general principle, with the exception of car insurance and to some extent insurance against work accidents, the rights of the insurer are defined by law, and any defense of the insurer against the insured shall be ruled under the insurance law and the insurance contract between them (Trebilcock, 1988). The former can use this against the other, too. One of these defenses is cancelling the insured's right in the insurance if the latter fails to submit correct information, or violating any of the conditions included in the document. One of these conditions is to resort to arbitration in case of dispute (Birds, 1987). 
Article No. 143 of the 1988 English Traffic Law has made insurance on cars compulsory, and therefore, any person cannot drive a car in Britain without insurance in favor of the other (Mance, 1995). Besides, article No. $153 / 3$ of the law in question recognizes the right of third parties to direct proceedings saying that, "nothing in paragraph (1) above affects any of the rights granted under the law" to third parties against insurance companies. Simply, they are rights granted against the person who issues the insurance policy. Furthermore, article No. 148/1 has identified certain items that have no effect on the rights of others. These items include age, mental and physical status of the driver, the condition of the vehicle itself, the number of persons in the vehicle, the size and quality of the goods carried, the area in which the vehicle is used, and carrying the vehicle identification documents, which are normally not required to be carried. This article has been included to restrict the insurer from placing any exceptions in the insurance document to avoid responsibility. We should note that the parties or litigants of direct suit are three. The first party is always the defendant or the insurer. The second party is the claimant, and he is often the injured or those who may replace him, such as beneficiaries or heirs provided that he has not been compensated for the damage that occurred to him. The third party is the insured who has to be included in the case sometimes (Arafa, 1950).

The suit that does not arise from an insurance contract is not covered by the three-year limitation period, which starts from the time of the accident that leads to the suit in question, and its source shall be the law rather than the insurance contract (Mansour, 2000). In other words, the limitation period is issued by law whether the liability is insolvent or contractual. This period lasts for fifteen years during which the injured can file the lawsuit at any time. However, two issues shall be taken into consideration. Keeping silent for a long time before filing the lawsuit can be interpreted as an implicit waiver of the case. The injured has the right to file a direct lawsuit as long as the insured approves it. If the latter denies this right due to statute of limitation, the injured cannot sue the insurer with a direct action. Filing a direct lawsuit requires certain conditions to gain acceptability before the court. We may summarize them as follows. The injured is the one who has the right to file a direct lawsuit against the insurer. The injured has not received the compensation within the limits of the insurance amount. The injured shall file a claim of responsibility against the insured and a direct lawsuit against the insurer. The injured shall prove he is a creditor to the insurance company. A direct lawsuit intends to ensure that the injured will receive compensation through insurance. If the injured is able to prove the percentage of mistake committed by the insured, and that the insurer is liable for compensating damages as per an insurance contract between the insured and the insurer, the result shall be on his behalf. Indeed, one main feature of a direct lawsuit determined by law in favor of the injured is that other creditors do not overwhelm him (Al-Ateer, 1995). Moreover, in a direct lawsuit, there is no legal relationship between the injured and the insurer. Instead, there is a tort liability relationship between the injured and the insured

The injured refers to the insured in case of claiming for compensation due to damages caused by the latter to the former in a car accident. Such claim could be amiable or judicial. The insured, in turn, at the realization of such damage shall refer to the insurer to claim for what he has already paid to the injured whether amiably or judicially (Rustad \& Koenig, 1992). Tort liability might be realized without the realization of the insured risk. The latter cannot be achieved until the injured claims for compensation. We can clearly note that civil liability insurance does not ensure the injured for the damage caused by the insured. It is not an insurance on people or property (James, 1948). It is a tort liability insurance in which the insured is obliged to compensate the injured for damages he causes while driving his car. The first item of article No. 1118 of the preliminary draft of the Egyptian Law confirms that this type of liability cannot be realized until the injured files a claim against the insured. In addition, article No. 1004 of the Iraqi Civil Law stipulates that no effect is achieved of the insurer's obligation as per an insurance contract until the injured files a claim against the insured. As stated above, this claim can be amiable or judicial. On one hand, an amiable claim shall be given by a legal notice, a recommended letter, a regular letter, or even an oral claim, but it shall be explicit so that the insured can prove it to the insurer to recover payment. On the other hand, a judicial claim in which the injured files a lawsuit against the insured away from the insurance company to obtain a judicial ruling that he will execute through the Department of Procedure. (IBID: 283).

As long as the car is insured, the insurance company is obliged to cover the damages that occur to others as a result of using the car. However, the date of the car accident is important in two ways (Vickrey, 1968). The accident that causes the damage shall occur during the validity of the insurance contract (Schroll, 2014). The accident has no effect at all if it occurs before signing the contract. But the claim for compensation is effective even if it is filed after the contract has expired provided that the accident has occurred during its validity. The date of the incident and not the date of the claim shall be deemed to protect the direct right of the injured towards the insure accordingly, the insured is obliged to inform the insurer of the accident and occurrence of damage as well as of the insured's claim for compensation. The second item of article No. 1118 of the preliminary draft of the Egyptian Law states that "the insured shall notify the insurer of the amiable claim within fifteen days from the date of its arrival, but if the claim is judicial, he should inform the insurer as soon as he receives it."

The insured and the injured may come to an amiable agreement for the tort liability resulted from the incident. The former may convince the latter of his irresponsibility of the accident (Sucharitkul, 1996). The injured may waive or keep his claim. It is possible sometimes to include the insurance contract a condition according to which the insured cannot hold an agreement with the injured without the knowledge of the insurer. Settling the tort liability with the injured judicially includes three possibilities (Gelhorn, 1987). The insured shall be solely responsible. It is too rare for the insured to face a judicial claim alone. The insurer becomes an opponent in the 
case, and this what often occurs and preferred by the insured as the lawsuits of liability and insurance are merged into one case. The insurance company manages the liability lawsuit. A condition is often included in the insurance contract according to which the insurer shall manage the direct lawsuit liability alone. This clause in the contract serves as an authorization to initiate proceedings on behalf of the insured.

In a compulsory car accident insurance, the legislator has protected the right of the injured in such accidents. The insured's obligation has been stripped of any defenses derived from the contract. Meanwhile, the legislator has not ignored the insurer's interests and rights. Accordingly, the insurance company can claim against the insured for the compensation the latter might pay to the injured in specific cases. This obligation comes as a result of legislating a direct lawsuit stripped of defenses for the injured. In other words, the legislator has allowed the insurer who pays the compensation to the injured to claim against the insured if the latter violates any of his obligations as per the contract. Article No. 16 of the law No. 652 as well as the fifth item of the insurance document stipulate that a compulsory car accident insurance contract shall include reasonable duties for the insured and acceptable restrictions for using the car. If the insured violates any of his obligations, the insurer has the right to claim against him to retrieve the compensation that the company has paid (Mansour, 2000). Moreover, article No. 75 of the Executive Regulations of the Traffic Law confirms that it is possible to include reasonable restrictions on the insured related using the vehicle and driving it provided that they do not contradict with the provisions of the Traffic Law and its decisions.

The insurer's right to claim against the insured is restricted by two entries. First Entry: The insurer has paid the compensation to the injured in one of the of the non-insurance cases as provided in articles No. $16 \& 17$ of the Law No. 652 of the year 1955. An example for that when the insurance becomes invalid due to giving false statements or hiding essential facts from the insurer. Second Entry: The insurer shall be liable for the compensation paid by the insured to the injured person. In other words, if the insured compensates the injured for the damages caused to the latter's property, the insurance company has the right to claim against the insured for unjustified enrichment. The insurer, however, can claim against the insured in specific cases. These cases will be described in details in the following sub-sections: This case is related to hiding essential events, or giving false statements, such as type of the vehicle, its condition, weight, number of passengers, type of fuel, purpose of license, use, power and cylinder engine capacity. Such false statements may affect the insurer's judgment on accepting risk coverage, or on determining the insurance value and its conditions (Hamouda, 1008). However, good or bad intentions are not taken into consideration whether the insurer has suffered damage or not. Simply, because cancelling the insurance document in this case is not an application of the contractual liability that requires error, damage and causative relationship.

\section{Methodology}

The researcher adopts a descriptive analytic method so as to describe, analyze and interpret the implications of an insurance contract. Furthermore, a comparative study is applied while referring to similarities and differences between the Emirati Car Insurance No. 25, 2016 as well as laws and legitimacies of other countries.

\section{Analysis}

This case is related to using the vehicle for purposes other than those stated in its license, such as transporting passengers, carrying cargo more than the determined load, or using it in racing, speed test and training. Paragraph (b) of article No. 76 of the Executive Regulations of the Traffic Law includes cases in which the wrongful use of the car. Any of these cases permits the insurer to claim against the insured. These cases are as follows. Firstly, Using the vehicle for a purpose other than that stated in its license book. Insurance and payment of premium are determined according to its use. We should note that a premium of a private car is different from that of a taxi or a bus. The insured, consequently, should comply with the purpose of the vehicle as identified in the license book. Violating this condition by the insured may lead to terminating the insurance. Nevertheless, the right of the injured is not affected by such procedure. Article No. 58 of the Executive regulations of the Traffic Law confirms that the insurer's claim against the insured shall not have any consequences that may affect the rights of the injured people. The insurance company is obliged to pay the required compensation to these people. Secondly, Number of passengers. The legislator permits the insurer to claim against the insured for the compensation paid to the injured if the number of passengers are more than that stated in the license.

Thirdly, Overloading the vehicle. Increasing the load of the vehicle may enlarge the likelihood of accidents. If the accident results from an overloaded vehicle, the insurer then has right to terminate the insurance and claims against the insured for the compensation paid to the injured. Fourth, Using the vehicle in a car race and in speed tests. This case includes two causes according to which, the insurer may claim against the insured, Using the vehicle in a car race and Using the vehicle in speed tests. In both cases, the vehicle is subject for more dangers, which exceed the normal use of the car that both parties have agreed upon in the insurance contract. This can be taken as a violation to the obligation of using the car for its main purpose as identified in the license. The insurer, therefore, has the right to terminate the insurance and claim against the insured. Five, the case of a drunken driver. If it has been proved that an accident has been caused by the insured or any other person allowed to drive the vehicle while he is under the effect of alcohol or any other type of drug, the insurer can terminate the insurance contract. As we stated above, the right of the injured shall not be affected by such action.

Not only that, six is Driving without or with a different type of license. The Traffic Law stipulates that a driving license must be obtained from the Traffic Department by passing a test before driving cars or other vehicles. According to legislation, driving a vehicle without license increases danger, and therefore, insurance shall be terminated. Article 76 of paragraph (d) of the Executive Regulations of the Traffic Law confirms that if 
the vehicle driver, whether the insured or any other person approved to drive the car, does not have a driving license, the insurer has the right to claim against the insured for the value of the compensation paid to the injured. Seven, Intentional action with prior determination. If it has been proved that death or injury has arisen from an act committed by the insured intentionally and with prior determination, such action shall not be covered by insurance. Insured risk must be probable, but if it turns to be deliberate, it loses the element of deliberateness. It should be noted, however, that the insurer's claim is limited to the insurer's deliberate action only. Eight, Inefficiency of the vehicle's equipment. If it has been proved that some of the vehicle's equipment are inefficient, especially the parking ones by more than $30 \%$ at the time of the accident, the insurer may claim against the insured and terminate the insurance document. Violating traffic rules. If the accident occurs as a result of driving opposite the traffic, breaking the red traffic light, exceeding the speed, or sudden deviation, the insurer may claim against the insured and terminate the insurance document (Al-Fuqqi, Hamza \& Bin Obeid, 2000). Finally, articles No. $16,17, \& 18$ of the Law No. 652 of the year 1955 stipulates that when dealing with the cases mentioned above, the rights of the injured shall not be prejudiced.

\section{Conclusion}

We may now conclude that. Arab and international legislation consider car insurance compulsory with some exceptions in order to compensate all those affected by a car accident. One major problem of a compulsory insurance is to come out with a unified definition to this type of insurance. Interpretations differ from one country to another. Arab and international legislation varies in excluding a range of cars or vehicle from insurance, such as those of the state, armed forces, etc. Arab and other foreign laws as well as the legitimate ones have differed in their choices of car insurance basis. Some of them have adopted the contractual basis, while others have considered the relationship between the insurer and the car owner as a legal one based on law rather than the contract. Islamic Sharia adopts the first type, i.e. the contractual basis. Many legislations in the field of compulsory insurance have limited the right of compensation to body damage. Some other legislations have covered damages of property, too. An essential objective of the Islamic Sharia is to achieve all fair interests of people. It has been working permanently on any emerging issue that concerns the nation and its interests, including insurance that is based on cooperation and solidarity for the purpose of repairing any damages that an individual alone cannot bear or undertake. Insurance have been made compulsory in certain fields to ensure that some groups shall receive compensation in case of injury. Most legislations have not specified the amount of compensation that the insurer is obliged to pay in case of injury, death, or property damages. This amount shall be determined by the court judgment. Most legislations confirm that the insurer is obliged to pay the compensation provided that the car accident has been committed by an insured. Arab insurance companies are still unstable in all aspects of business if compared to foreign insurance companies.

\section{Recommendations}

We may recommend the following. Premiums shall be determined according to the traffic record of the insured. Premium shall be increased if violation increases, and vice versa. A law shall be enacted to ensure that the injured is reasonably compensated for body injuries and property damages that result from a car accident. Expanding the vehicle concept to include not only people's cars, but also cars that do certain work. All passengers of private and public vehicles, including the driver, shall be compensated for body injuries or property damages that result from a car accident. These compensations must be expanded to cover future damages as long as there is a clear causal link between them and the car accident

\section{References}

1. Abraham, K. S., \& Rabin, R. L. (2019). AUTOMATED VEHICLES AND MANUFACTURER RESPONSIBILITY FOR ACCIDENTS. Virginia Law Review, 105(1), 127-171.

2. Aguilar, A. G., Ward, P. M., \& Smith Sr, C. (2003). Globalization, regional development, and mega-city expansion in Latin America: analyzing Mexico City's peri-urban hinterland. Cities, 20(1), 3-21.

3. Al-Ateer, Abdul Qadiri (1995). Land Insurance in Jordanian Legislation. Amman: Al Thaqafa Bookshop for Publishing \& Distribution.

4. Al-Deeb, Ali Al-Sayed (1993). Car Insurance. Cairo: Computer Center.

5. Al-Fuqqi, Al-Siba'i Mohammad, Mahmood Jamaliddin Hamza \& Fahad Saqr Bin Obeid (2000). Principles of Insurance. Kuwait: Thatilsalasil Press.

6. Al-Hanci, Mukhtar Mahmoud \& Usama Abdul Aziz Hussein (1992). Risk and Insurance. Alexandria: Al Isha'a Press.

7. Al-Jundi, Jameel (1998). Future of Insurance Industry in the United Arab Emirates. Abu Dhabi: Insurance House.

8. Al-Qaradaghi, Ali Mohyildin (1979). Islamic Insurance: An Originating Jurisprudential Study. . Beirut: Dar Al-Basha'ir Al-Islamiya, p. 37.

9. Al-Sanhouri, Abdul Razzaq (1964). Al Waseet in Explaining the Civil Code. Al Gharar Contracts, Part VII, Volume II. 
10. Abulleil, Ibrahim Desouqi (1995). Insurer's Obligation for Compensation and Extent of Cla imagainst the Insured and Third Parties. Kuwait: Al Faisal Press.

11. Al-Sanhouri, Abdul Razzaq (2004). Al Waseet in Explaining the Civil Code: Insurance Contract, Gambling \& Salary for Life. Alexandria: Dar Al Ma'arif.

12. Al-Zayla'i, Othman Bin Ali (1314). Tabyeen Al-Haqa'iq fi Sharh Kanz Al-Daqa'iq. Al-Matba'a AlAmeeriyah Al-Kubra, Edition No. 01, Part 04, P. 548.

13. Arafa, Mohammad Ali (1950). Insurance and Small Contracts. Cairo: Fouad the First University Press.

14. Birds, John (2013). Bird's Modern Insurance Law. United Kingdom: Sweet \& Maxwell.

15. Baert, P., \& Da Silva, F. C. (2010). Social theory in the twentieth century and beyond: Polity.

16. Baker, T. (1993). Constructing the insurance relationship: Sales stories, claims stories, and insurance contract damages. Tex. L. Rev., 72, 1395.

17. Beck, U. (1992). From industrial society to the risk society: Questions of survival, social structure and ecological enlightenment. Theory, culture \& society, 9(1), 97-123.

18. Bovbjerg, R. R., Sloan, F. A., \& Blumstein, J. F. (1988). Valuing life and limb in tort: Scheduling pain and suffering. Nw. UL Rev., 83, 908.

19. Cotran, E., \& Lau, M. (2005). Yearbook of Islamic And Middle Eastern Law:(2003-2004) (Vol. 10): BRILL.

20. Council, N. R. (2006). Facing hazards and disasters: Understanding human dimensions: National Academies Press.

21. Cowley, A., \& Cummins, J. D. (2005). Securitization of life insurance assets and liabilities. Journal of Risk and Insurance, 72(2), 193-226.

22. Calabresi (1984). Economic Analysis of Law. In IOWA Law Review, Issue No.99, Jan. 01, 1984.

23. Clarke, Malcolm A. (2006). Law of insurance Contracts. London: Informa.

24. Desouqi, Ali Al Sayed (1955). Liability Insurance. Cairo: Dar Al Nahdha Al Arabeya

25. De Búrca, G., \& Scott, J. (2006). Law and New Governance in the EU and the US: Bloomsbury Publishing.

26. Gelhorn, W. (1987). Medical Malpractice Litigation (US)-Medical Mishap Compensation (NZ). Cornell L. Rev., 73, 170.

27. Greenblatt, J. A. (1997). Insurance and Subrogation: When the Pie Isn't Big Enough, Who Eats Last? The university of Chicago law review, 64(4), 1337-1366.

28. Griffith, S. J. (2005). Good faith business judgment: A theory of rhetoric in corporate law jurisprudence. Duke LJ, 55, 1.

29. Halpern, P., Trebilcock, M., \& Turnbull, S. (1980). An economic analysis of limited liability in corporation law. The University of Toronto Law Journal, 30(2), 117-150.

30. James, F. (1948). Accident liability reconsidered: the impact of liability insurance. The Yale Law Journal, 57(4), 549-570.

31. Keeton, R. E. (1954). Liability insurance and responsibility for settlement. Harvard Law Review, 67(7), 1136-1186.

32. Fahmi, Khalid Mustafa (2005). Compulsory Insurance Contract. Cairo: New University Publisher.

33. Lemaire, J. (2013). Automobile insurance: actuarial models (Vol. 4): Springer Science \& Business Media.

34. Mullerat, R. (2010). International corporate social responsibility: the role of corporations in the economic order of the 21st century: Kluwer Law International BV.

35. Peden, M., Scurfield, R., Sleet, D., Hyder, A. A., Mathers, C., Jarawan, E., . . Jarawan, E. (2004). World report on road traffic injury prevention: World Health Organization.

36. Petersilia, J. R. (2001). Crime victims with developmental disabilities: A review essay. Criminal justice and behavior, 28(6), 655-694.

37. Haikal, Abdul Aziz Fahmi (1985). Principles in Insurance. Cairo: Dar Al Nahdha Al Arabeya.

38. Hamid, Taj Al Sir Mohammad (2003). Insurance Contract. Sudan: Shareeh Al Qadhi Center.

39. Hamouda, Ibrahim Ahmed Abdul Nabi (1998) Principles of Insurance. Alexandria: University Press.

40. Hassan, Hussain Hamid (1979). Rule of Sharia on the Contracts of Insurance. Dar Al-I'tisam for Printing, Publication and Distribution,

41. Ibn Rushd, Muhammad Bin Ahmed (1988). Al-Muqadimat wa Al-Mumahidat, verified by Muhammad Haji, First Edition. Beirut: Dar Al-Gharb Al-Islami.

42. Jamal, Mustafa Mohammad (1998). Al Waseet in Private Insurance. United Arab Emirates: Publications Department. 
43. Khatir, Noori Hamad (2001). Informatics Contracts. Amman: Dar Al Thaqafa for Publishing \& Distribution.

44. Mance, Sir J. (1995). Insolvency at Sea. In LMCLQ. Issue No. 34, P. 143.

45. Mansour, Mohammad Hussein (2000). Car Accidents Liability. Alexandria: New University Publisher.

46. Mohammad Al-Siddiq, Abdul Quddous Abdul Razziq (2000). Liability Insurance and its Contemporary Mandatory Applications. Egypt: Al-Imam Al-Bukhari Bookshop for Publishing \& Distribution.

47. Murqus, Suleiman (1971). Civil Liability in Arab Countries Laws: General Provisions. Cairo: Al Jabalawi Press.

48. Mursi, Mohammad Kamil (1952). Explanation of the New Civil Law: Named \& Insurance Contracts. Part III. Cairo: International Press.

49. Ogrese, Mohammad (1992). Liability Insurance in the Moroccan Legislation. Morocco: Cordoba Press.

50. Yas, H., Alsaud, A., Almaghrabi, H., Almaghrabi, A., \& Othman, B. (2021). The effects of TQM practices on performance of organizations: A case of selected manufacturing industries in Saudi Arabia. Management Science Letters, 11(2), 503-510.

51. Yas, H., Jusoh, A., Abbas, A. F., Mardani, A., \& Nor, K. M. (2020). A review and bibliometric analysis of service quality and customer satisfaction by using Scopus database. International Journal of Management (IJM), 11(8).

52. Khudhair, H. Y., Jusoh, A., Mardani, A., Nor, K. M., \& Streimikiene, D. (2019). Review of Scoping Studies on Service Quality, Customer Satisfaction and Customer Loyalty in the Airline Industry. Contemporary Economics, 13(4), 375-388.

53. Sabir, Mohammad Ghazi (1993). Accident Insurance. Cairo: University of Cairo, College of Pharmacy, Computer Center.

54. Shahada, Saleh \& Ezzat Mohammad Abdallah (1988). Car Insurance. Iraq: High Education Press.

55. Sultan, Anwar (1962). General Theory of Obligation: Obligation Sources. Egypt: Dar Al Maarif.

56. Wasif, Saad (1958). Liability Insurance: A Study on Land Transport Contract. Cairo: University of Cairo, College of Law.

57. Zaki, Mahmoud Jamal Al-Din (1978). Problems of Civil Liability. Cairo: University of Cairo Press.

58. Robinson, P. H. (1975). A theory of justification: societal harm as a prerequisite for criminal liability. UCLA L. Rev., 23, 266.

59. Rustad, M., \& Koenig, T. (1992). The historical continuity of punitive damages awards: reforming the tort reformers. Am. UL Rev., 42, 1269.

60. Schroll, C. (2014). Splitting the bill: creating a national car insurance fund to pay for accidents in autonomous vehicles. Nw. UL Rev., 109, 803.

61. Shell, G. R. (1991). Opportunism and trust in the negotiation of commercial contracts: Toward a new cause of action. Vand. L. Rev., 44, 221.

62. Sucharitkul, S. (1996). Responsibility and Liability for Environmental Damage Under International Law.

63. Trebilcock, M. J. (1988). The role of insurance considerations in the choice of efficient civil liability rules. JL Econ. \& Org., 4, 243.

64. Vickrey, W. (1968). Automobile accidents, tort law, externalities, and insurance: an economist's critique. Law and Contemporary Problems, 33(3), 464-487. 